\title{
DETERMINATION OF THE TOLUENE CONTENT OF A MIDCONTINENT PETROLEUM ${ }^{1}$
}

\author{
By Johannes H. Bruun, ${ }^{2}$ R. T. Leslie, ${ }^{2}$ and Sylvester T. Schicktanz ${ }^{2}$
}

ABSTRACT

Commercial petroleum fractions from an Oklahoma crude oil were subjected to an extensive fractional distillation culminating in a set of $1^{\circ}$ cuts. Toluene was found in all of the cuts boiling within the range $90^{\circ}$ to $112^{\circ} \mathrm{C}$. The amount in each cut was determined by nitrating it quantitatively to 2, 4-dinitrotoluene by means of a nitrating procedure which was found not to attack any of the other constituents of the fractions.

Practically all of the toluene was found in the fractions boiling below $110^{\circ} \mathrm{C}$. the boiling point of pure toluene. The largest fraction, boiling between $98^{\circ}$ and $99^{\circ} \mathrm{C}$. contained the larger amount of toluene, but the maximum concentration of toluene ( 32 per cent) was found in the fraction boiling between $107^{\circ}$ and $108^{\circ} \mathrm{C}$. The total amount of toluene found corresponded to one-third of 1 per cent based upon the crude petroleum.

\section{CONTENTS}

I. Introduction

Page 363

II. Methods employed

III. Experimental procedure

1. Distillation 365

2. Nitration 366

IV. Discussion of results

V. Acknowledgment

\section{INTRODUCTION}

$\Lambda$ variety of methods have been proposed and used for the determination of the aromatic hydrocarbons (as a group) in various petroleum fractions, and a few attempts have been made to determine the amount of an individual hydrocarbon of this class in a given crude oil. Schorlemmer ${ }^{3}$ was one of the first to prove the presence of toluene in a Pennsylvania crude oil. Mabery, ${ }^{4}$ in his pioneer work on American petroleum, estimated that an Ohio petroleum contained about 0.03 per cent of toluene, Mabery and Hudson ${ }^{5}$ found 54 per cent of toluene in the fraction of a California petroleum which distilled between $109^{\circ}$ and $110^{\circ} \mathrm{C}$. Most of the toluene in this crude oil was found in the fractions which distilled near the normal boiling point of pure toluene $\left(110^{\circ} \mathrm{C}\right)$. However, Young, ${ }^{6}$ in working with a Pennsylvania oil, noticed that most of the toluene distilled far below its own boiling point.

1 This paper describes some of the results obtained in an investigation on The Separation, Identification, and Determination of the Chemical Constituents of Commercial Petroleum Fractions, listed as project No. 6 of the American Petroleum Institute Research. Financial assistance in this work has bcen received from a research fund of the $\Lambda$ merican Petroleum Institute donated by John D. Rockefeller. This fund is being administered by the institute with the cooperation of the Central Petroleum Committee of the National Research Council.

2 American Petroleum Institute research associate.

3 C. Schorlemmer, Lieb. Ann., 127, p. 311; 1863.

C. F. Mabery, Proc. Am. Acad., 31, p. 34; 1894.

$\checkmark$ C. F. Mabery and E. I. Hudson, Proc. Am. Acad., 36, p. 259; 1901.

S. Young, J. Chem. Soc., 73, p. 918; 1898. 
The amount of toluene in petroleum fractions has usually been determined by treatment with a mixture of nitric and sulphuric acids, the decrease in volume after this treatment being used as a direct measure of toluene. This method is also used for the determination of aromatic hydrocarbons as a group in petroleum fractions and has been described by Egloff and Morrell ${ }^{7}$ and by Faragher, Morrell, and Levine. ${ }^{8}$

In the investigations on an Oklahoma petroleum four of the isomers of hexane ${ }^{9}$ as well as $n$-octane ${ }^{10}$ have previously been isolated. The present paper, which is a continuation of these investigations, describes the detection of toluene in the same oil and its removal and determination by means of nitration.

\section{METHODS EMPLOYED}

The lower boiling fractions of an Ollahoma petroleum were first fractionated by distillation into $1^{\circ}$ cuts. Preliminary nitration tests indicated that toluene was present in all fractions boiling between $90^{\circ}$ and $112^{\circ} \mathrm{C}$. The absence of other nitratable aromatic constituents, such as benzene and xylenes in these particular fractions, was proved by comparing the melting points of the preliminary nitro products with the melting point of pure 2,4 -dinitrotoluene. It was also proved by the absence of nitratable material in the fractions boiling immediately above and below those containing the toluene. The presence of benzene and of xylenes in other fractions will be discussed in a later paper.

The absence of unsaturated compounds was demonstrated by means of the iodine numbers which were found for the fractions before nitration.

The toluene was then removed from the fractions by treatment with the following nitrating mixture:

10 volumes $\mathrm{H}_{2} \mathrm{SO}_{4}, 66^{\circ}$ Bé. (specific gravity 1.84).

2 volumes $\mathrm{H}_{2} \mathrm{SO}_{4}$, fuming (23 per cent free $\mathrm{SO}_{3}$ ).

15 volumes $\mathrm{HNO}_{3}$, fuming (specific gravity 1.49 to 1.50 ).

By the use of this concentrated acid at low temperatures it was found possible to convert practically all of the toluene into 2, 4-dinitrotoluene without any appreciable amount of mononitro products (or trinitrotoluenes).

Before nitration the hydrocarbons were cooled to about $5^{\circ} \mathrm{C}$. The nitrating acid was added dropwise while rapidly agitating the mixture, which was maintained at all times below $10^{\circ} \mathrm{C}$. When all the acid had been added, a rapid agitation was continued for 30 to 60 minutes. The hydrocarbon layer was separated in a separatory funnel, after which the acid layer containing the dinitrotoluene was poured into a beaker containing crushed ice and agitated for half an hour. The dinitrotoluene was then filtered, washed with water, and dried. A small amount of dinitrotoluene mixed with mononitrotoluene remained in solution in the hydrocarbon layer. This amount was recovered by subsequent distillation. Traces of mononitrotoluene, which were obtained in this way, were converted into the dinitrotoluene by

\footnotetext{
7 A. Eglofi and J. C. Morrell, Ind. Eng. Chem., 18, p. 354; 1926.

${ }^{8}$ W. F. Faragher, J. C. Morrell, and I. M. Levine, Ind. Eng. Chem., Anal. Ed., 2, p. 18; 1930; and the references there cited.

J. H. Brumn and M. M. Hicks-Bruun, B. S. Jour. Research, 5, pp. 933-42; 1930.

10 R. T. Leslie and S. 'T. Schicktanz, B. S. Jour. Research, 6, p. 377; 1931.
} 
further nitration. From the weight of the dinitrotoluene the amount of toluene was then calculated.

The melting point of each nitro-product was determined. Owing to the presence of small amounts of occluded monitrotoluene and unnitrated hydrocarbons, the melting point was in some cases a few degrees below $70^{\circ} \mathrm{C}$. (the melting point of pure dinitrotoluene), but by crystallization from alcohol the melting point could in every case be raised to $70^{\circ} \mathrm{C}$.

A blank run on an unnitrated toluene-free fraction indicated that the nitrating treatment did not remove or attack the aliphatic or the naphthenic hydrocarbons.

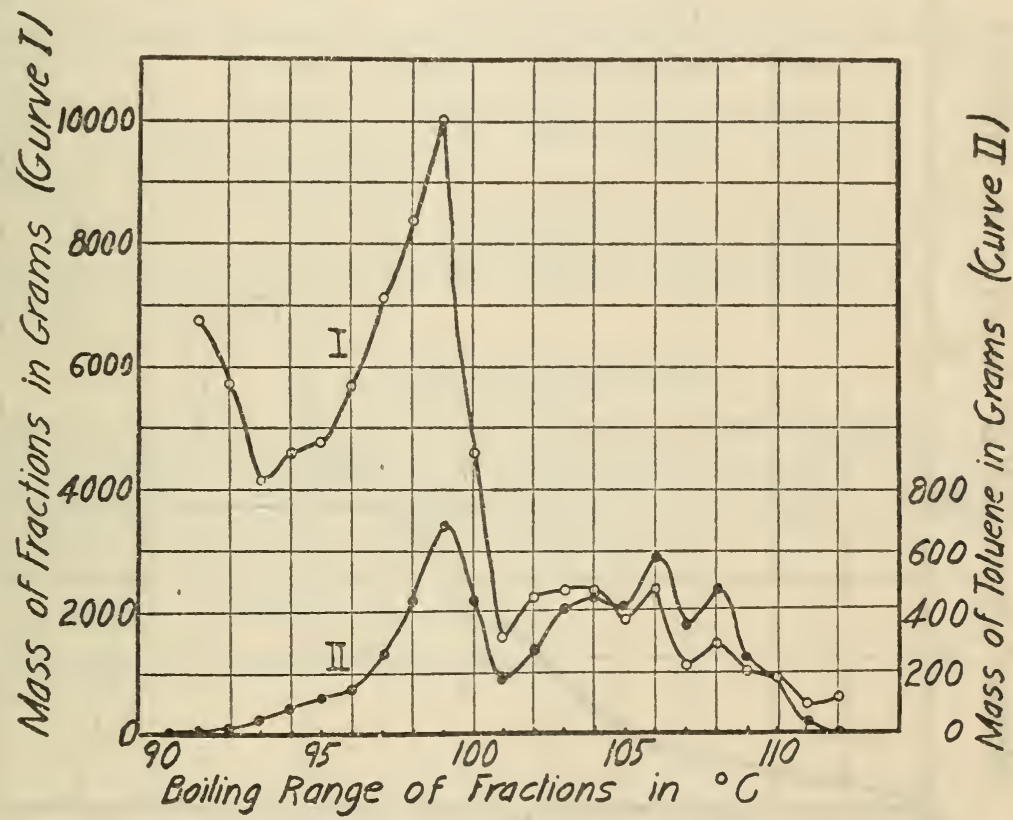

FIgURE 1.-Distribution of the distillates (Curve $I$ ) and of the toluene (Curve II) after extensive fractional distillation

Curve I shows the weight of fraction (left ordinate scale) plotted against boiling range. Curve II shows the weight of toluene in fraction (right ordinate scale) plotted against boiling range of fraction. Each point on the curve indicates the end point of a given cut.

Another test was carried out with petroleum ether free from aromatic and olefine hydrocarbons. Two grams of toluene were added to $200 \mathrm{ml}$ of the petroleum ether. During the subsequent nitration no petroleum ether was lost and the toluene was quantitatively recovered as dinitrotoluene.

\section{EXPERIMENTAL PROCEDURE}

\section{DISTILLATION}

The material used was of the lower boiling fractions from 600 gallons of crude oil, ${ }^{11}$ which had been distilled in a scmicommercial still

11 The crude was obtained from No. 6 Well of South Ponca Field, Kay County, Okla. See Washburn, Bruun, and Hicks, Bur. of Stds. J. of Res., 2, p. 469, 'Table I; 1929. 
in an oil refinery. ${ }^{12}$ Three hundred to four hundred liters of this material was first fractionated in a laboratory rectifying still ${ }^{13}$ with 20 bubbling cap plates ${ }^{14}$ of steel. The fractions from the laboratory still having boiling point ranges from $70^{\circ}$ to $130^{\circ} \mathrm{C}$. were subjected to extensive fractional distillation in smaller bubbling cap stills ${ }^{1014}$ of Pyrex laboratory glass. These distillations were carried out at a rate of about $1 \mathrm{ml}$ per minute and with a reflux ratio of about $10: 1$. A fraction was taken for every $1^{\circ}$ increase in the temperature of distillation. In this way 60 different fractions were obtained between the

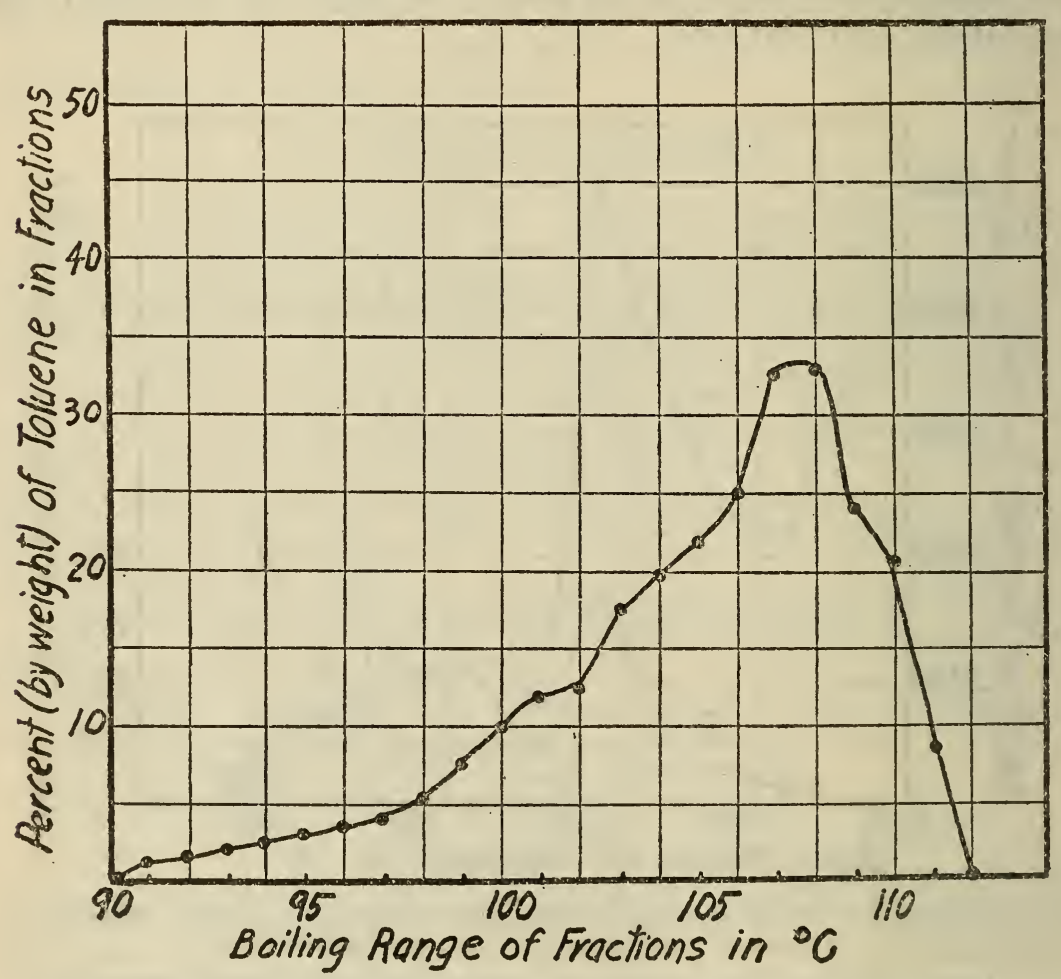

FigURE 2.-Percentage of distribution of toluene in fractions after extensive fractional distillation

Ordinate: Percentage of toluene in fraction. Abscissa: Boiling range of fraction.

temperatures $70^{\circ}$ and $130^{\circ} \mathrm{C}$. Toluene was found in 22 of the fractions which had distilled within the range $90^{\circ}$ to $112^{\circ} \mathrm{C}$. and was removed by nitration.

\section{NITRATICN}

Each of the fractions boiling within the range $90^{\circ}$ and $112^{\circ} \mathrm{C}$. was nitrated according to the method described. The result of the nitration is shown in Figures 1 and 2.

10 R. F. Leslie, and S. T. Schicktanz, B. S. Jour. Research, 6, p. $377 ; 1931$.

12 Acknowledgment for this distillation is made to A. E. Pew, Jr., and K. B. Davioison of the Sun Oil Company.

13 E. WW. Washburn, J. H. Bruun, and M. M. Hicks, Bur. of Stds. J. of Res., 2, pp. 470-3; 1929.

14 J. H. Bruun, Ind, Eng. Chem., Anal. Ed., I, N. 212; 1929. 


\section{DISCUSSION OF RESULTS}

Curve 1 in Figure 1 shows the distribution of the distillates over the boiling range. The largest $1^{\circ}$ cut is that boiling between $98^{\circ}$ and $99^{\circ}$ C. Curve 2 in Figure 1, representing the distribution of the toluene in the different fractions, shows that the large fraction boiling between $98^{\circ}$ and $99^{\circ} \mathrm{C}$. contained a larger amount of toluene $(683 \mathrm{~g})$ than any of the others.

The percentage of toluene by weight in the fractions is represented by the graph in Figure 2, which shows that the maximum concentration (32.2 per cent) of toluene is present in the fraction boiling between $107^{\circ}$ and $108^{\circ} \mathrm{C}$. This is in accordance with the statement made by Young that the toluene in petroleum fractions distills below its own boiling point. This can probably be explained by the existence of a constant boiling mixture of toluene with other constituents of petroleum. The search for these other constituents is in progress and will be described in a later paper.

A total of $11,589 \mathrm{~g}$ of dinitrotoluene equivalent to $5,858 \mathrm{~g}$ of toluene was obtained as a result of the nitration. Based upon 600 gallons of crude petroleum (specific gravity 0.9) the toluene content is found to be one-third of 1 per cent.

\section{ACKNOWLEDGMENT}

The authors wish to express their thanks to E. W. Washburn, chief of the chemistry division, Bureau of Standards, and director of American Petroleum Institute Research Project No. 6, under whose direction this investigation has been carried out.

The authors are indebted to H. A. Barron for assistance rendered in the laboratory during this work.

Washington, December 20, 1930. 